\title{
Sebejisté a troufalé, ale ne vzrušující. Osobnost značek českých politických stran $v$ perspektivě prvovoličů
}

\author{
Confident and Daring, but Unexciting: Brand Personality \\ of the Czech Political Parties as Perceived by First-Time Voters. \\ Jiří Šimon, Roman Chytilek'
}

\begin{abstract}
The article deals with the concept of political brand, focusing on brand personality. Up until now, the debate in political science has mainly revolved around the issue of the proper conceptualisation and measurement of the phenomenon, with most contributions coming from UK political scientists. Our aim is to discuss the merits and limits of transferring existing conceptual and research tools into the Czech context. The finding is that the commonly used six-dimensional model (Smith 2009) can be employed in the Czech settings as well. However, when it comes to brand personality, none of the established Czech political parties can claim its personality is perceived uniformly across a sample of first-time voters. Agreement about the nature of any given party's personality is of a somewhat higher level among those who tend to see that party in positive terms.
\end{abstract}

KEYWORDS political brand, political parties, political marketing, brand personality

Značky jsou dnes nesporně jednou ze základních hodnot tvořících kmenové bohatství institucí, jež je vlastní. Žijí uvnitř srdcí i myslí lidí, jež je často využívají k vyjádření své osobnosti a společenského statusu, popř́padě prostř̌ednictvím značky prezentují své názory a přesvědčení. Značky tak představují stále důležitější element v rozhodování lidí. Jak výstižně uvádí Margaret Scammell, ,značky jsou nyní všude, nepoužívají se již pouze ve spojení s produkty, společnostmi, organizacemi a známými osobnostmi, ale také s městy, národy a dokonce i se soukromými osobami“" (Scammell 2009: 178).

Ale ani dobře a výstižně zvolená značka nemusí v konkurenci s ostatními obstát. Je nezbytné, aby se stala v myslích svých potenciálních uživatelů nositelkou hodnoty, kterou získají její volbou. Pokud je značka v jejich myslích efektivně zakotvena, dokáží si ji uživatelé vybavit, spojit si ji s prvky, které využívá při své prezentaci, určit, jakou pozici na trhu zaujímá, a popsat její charakter. Značka je pak mnohem víc než jen pouhým nástrojem

Sociálni studia. Katedra sociologie FSS MU, 3/2011. S. 39-63. ISSN 1214-813X.

1 Text vznikl v rámci výzkumného záměru „Politické strany a reprezentace zájmů v soudobých evropských demokraciích“ (kód MSM0021622407). Autoři děkují anonymním recenzentům za cenné poznámky $\mathrm{k}$ textu. 
k odlišení se od ostatních. Stává se nositelkou přidané hodnoty, kterou uživatelé vnímají a která pomáhá při jejich rozhodování.

Jak uvádí Kevin Lane Keller, mohou být principy značky ve skutečnosti aplikovány prakticky v každé situaci, kdy je uživatel postaven před možnost volby nějakého druhu např́íklad zboží, služeb, osob, organizace, místa nebo dokonce myšlenky (Keller 2002: 151 in Smith-French 2009). Politické strany lze vnímat jako organizace budující svou značku, aby dosáhly volební podpory. Koncept značky představuje zajímavou výzkumnou oblast i pro politologický výzkum.

Růst zájmu o politické značky bývá spojován se změnami, které prodělaly západní demokracie v 60. letech 20. století s tzv. „rozmrznutím“ západoevropských stranických systémů (srovnej Lipset a Rokkan 1967: 50-56, Dalton 2002), kdy došlo k otevření do té doby uzavřeného volebního trhu. Voliči začínali být při rozhodování stále méně ovlivněni svým socioekonomickým statusem. Strany (hlavně masové strany) se v důsledku eroze tradičních sociálních hranic a růstu sociální mobility přestaly orientovat pouze na relativně omezený sociální segment a začaly se snažit o rozšiřrení své voličské základny. V dané souvislosti se mluví o nástupu „tzv. univerzálních stran (catch-all parties)“, které se namísto dosavadních integračních strategií zaměřily na získání sociálně různorodých voličů. Aby mohly oslovit co nejširší skupinu voličůu, musely volit strategii rozšíření svého programového záběru a omezení intenzity ideologického konfliktu, na jehož základě se utvářely předchozí masové strany (Kopeček 2005: 16). V situaci, kdy se programové nabídky a ideologická vzdálenost stran posouvaly stále více do středu politického spektra, začínaly značky stran představovat efektivní nástroj k odlišení jednotlivých stran v rámci politického trhu a pomáhaly voličům usnadňovat jejich rozhodování. Pokud je politická značka pevně zakotvena v myslích voličů, kteří si ji dokáží spojit s přidanou hodnotou, kterou jim její volba přináší, představuje velmi efektivní nástroj pro ovlivnění jejich rozhodnutí volit danou stranu.

Ke zkoumání značek pak můžeme přistupovat ze dvou stran. První přístup se orientuje na způsoby, jakými strany (a obecně instituce) budují a řídí své značky. Jedná se tedy o sledování tzv. strategického řízeni značky (brand management). Tyto výzkumy se snaží odkrýt mechanismy, jakými jsou značky uváděny na trh, jak je budována a ř́zena jejich hodnota, identita a osobnost. Druhý přístup pak reprezentují výzkumy věnující se vnímání značky z pohledu uživatelů značky. Tedy tomu, jak reagují uživatelé na značku, jakými znalostmi o značce disponují a jaké hodnoty jí přisuzují.

Následující text je věnován problematice vnímání politických značek a představuje výsledky výzkumu vnímání politických značek u skupiny prvovoličů v České republice. Je otázkou, zda a proč je vůbec důležité zabývat se politickými značkami a jejich výzkumem u nás. Značky představují nástroj, který by mohl ulehčovat rozhodování při potenciální volbě za předpokladu, že jsou v myslích potenciálních voličů již ukotveny. V rámci prŕípadové studie, která je součástí textu, se snažíme odpovědět na otázku, zda se v České republice daří politickým stranám budovat v myslích potenciálních voličů prŕznivé a ucelené obrazy svých značek. Zaměřujeme se přitom na specifickou oblast, která bývá označována jako osobnost značky a jejíž teoretické vymezení zahrnuje úvodní část textu. Díky skutečnosti, že se zkoumání značek historicky nejsilněji rozvíjelo v západoevropském prostředí, vycházejí teoretické rámce, uvedené v textu, právě z této oblasti. Práce pak využívá koncepty vycházející 
z ekonomického diskursu, jejichž relevance pro politologický výzkum značek byla testována předchozími studiemi v západoevropském prostředí (text vychází hlavně z prací britských autorů).

Předložený text je strukturován do několika logicky navazujících částí. Nejprve si ve zkratce všímáme impulzů, které vedly k rozvoji akademických úvah o politických stranách jako značkách. Následuje představení konceptu „osobnosti“ značky a nástrojů určených $\mathrm{k}$ jeho měření. $\mathrm{V}$ poslední části jsou prezentovány výsledky výzkumu vnímání osobnosti značky sedmi českých politických stran skupinou prvovoličů, který proběhl během března 2011 na vzorku studentů čtyř nejvyšších ročníků českých gymnázií. Těmito stranami bylo pět parlamentních stran - ODS, ČSSD, TOP 09, VV a KSČM -, které byly doplněny o dvě bývalé parlamentní strany z předchozího volebního období (KDU-ČSL a SZ). V závěru jsou pak diskutována hlavní zjištění výzkumu.

\section{Nástup politických značek}

Značky představují důležitý element v rámci politického (volebního) trhu. Dokáží ve vnímání voličů produkovat rozdíly mezi konkurenčními nabídkami, mohou hrát rozhodující roli ve voličských preferencích a ovlivňovat rozhodování voličů. Existuje řada prací, které se dívají na politické strany nebo jednotlivé politiky jako na značky (Schneider 2004, Smith 2009, Smith-French 2009, Scammell 2007). Jednou z příčin vedoucích ke zvýšenému zájmu o výzkum politických značek byla měnící se povaha poválečných západních demokracií. Kirchheimer naznačuje, že pohlížení na politické strany jako na značky je nevyhnutelná reakce na přechod od masových stran směrem ke stranám univerzálního (catch-all) typu. Voliči jsou při svém rozhodování méně ovlivněni třídní příslušností (socio-ekonomickým statusem) a začínají se chovat jako racionální subjekty (Kirchheimer 1996 in Smith-French 2007: 461). Z tohoto důvodu musí být pro výhru ve volbách „univerzální strany v milionech myslí zakotveny jako známý objekt splňující v politice roli analogickou s velkými značkami z oblasti komerčního marketingu“ (Kirchheimer 1966: 192 in Smith-French 2007: 461). Hlavním předpokladem univerzálního (catch-all) př́stupu je, že politické strany v mnoha západních demokraciích stále bojují o voliče pohybující se ve středu stranického spektra. $\mathrm{K}$ zajištění této středové pozice nabízejí strany voličům svůj volební program v podobě, na níž se všichni shodnou (např́klad nutnost zlepšit veřejné služby), a liší se pouze v prostředcích $\mathrm{k}$ dosažení stanovených cílů. Pro voliče je tak čím dál obtížnější nalézt rozdíly potřebné k rozlišení stran (Smith-French 2007: 461).

Pokud se ptáme, zda popsaný vývoj lze vztáhnout i na Českou republiku, není k dispozici zcela jednoznačná empirická evidence. Expertní průzkum hlavních českých politických stran (Chytilek a Eibl 2011) např́klad naznačil, že k reprezentaci stranickopolitického konfliktu v ČR v dimenzi politických témat (policy) je stále validní používat jednu osu konfliktu, reprezentovanou převážně socioekonomickými tématy, přičemž výsledná vzdálenost mezi hlavními stranickými póly byla poměrně velká. Naproti tomu kvantitativní analýza volebních programů českých politických stran pro parlamentní volby v roce 2010 (Eibl 2010) ukázala, že ideologická vzdálenost mezi stranami nebyla tak velká, jak by se dalo na první pohled předpokládat (například podle vyhrocenosti předvolební kampaně v ČR). Celkově 
bylo hodnoceno sedm politických stran. Čtyři z nich (ČSSD, KDU-ČSL, VV a SZ) se umístily v těsné blízkosti pomyslného středu politického spektra. ODS a TOP 09 se umístily napravo od pomyslného středu a KSČM pak zaujala pozici nalevo. Použitý index mohl teoreticky nabývat hodnot od -100 do 100 . Všechny sledované strany se pak pohybovaly v rozmezí 37 bodů, které představovaly vzdálenost mezi dvěma krajními stranami (ODS napravo a KSČM nalevo). Programy českých politických stran „zdaleka nepokrývají možnosti, které jim index nabízí, a lze je proto označit za ideologicky umírněné“ (Eibl 2010: 84). Můžeme tedy konstatovat, že i v rámci České republiky se strany „snaží vytvořit ideální mix politik a řešení, který by dokázal oslovit co možná největší počet voličư “ (tamtéž). Proto není neobvyklé, že pravicové strany mají ve svém programu politiky, které jsou tradičně vnímány spíše jako levicové (a vice versa).

Zároveň je nutné poznamenat, že jen velmi málo občanů participuje na stranické politice. Pro většinu občanů je shromažd'ování politických informací nákladné, porovnáme-li úsilí potřebné k jejich získání s motivací (Downs 1957). Je proto opodstatněné předpokládat, že nízká angažovanost voličů bude provázena poměrně malou znalostí politických stran. Voliči s nízkou angažovaností jsou ovšem stále schopni používat heuristiku při svém rozhodování, koho volit. Například obraz lídra strany, jako hlavní a často dominantní prvek celé značky, může být označen jako heuristika pro hodnocení celé strany - její způsobilosti, toho, jak je vnímaná, a její přitažlivosti (Smith a French 2007: 461).

\section{Politické strany jako značky}

Voliči mají jistou schopnost vybavit si názvy politických stran, v menší míře jejich symboly. Přikládají význam názvům a symbolům v průběhu času. Významy následně umožňují rozlišovat ve volbách volenou stranu od ostatních. Stojí za zmínku, že tento efekt velmi dobře funguje na komerčních trzích. Zde bylo u značek prokázáno, že vyvolávají vnímání rozdílů mezi konkurenčními značkami. Mají klíčovou roli v řízení spotřebitelských preferencí a hlavně ve spotřebitelské volbě (Aaker 2003).

To vedlo k rozvoji teze, že voliči mají znalosti o politických stranách strukturované podobným zpo̊sobem jako $\mathrm{v}$ případě komerčních značek, například těch, které představují VW nebo Ford (Schwieger a Adami 1999: 348). Ukazuje se, že povědomí voličů o značkách politických stran, jejich představitelích a hodnotách je poměrně přesné (Smith a French 2009). To ovšem neznamená, že voliči (elektorát) se vyznačují unifikovanou znalostí politických značek.

Politické značky mají tři zřetelné elementy: stranu jako značku, politiky jako hmotné představitele a jednotlivé politiky (policy) jako jádro nabídky svých služeb (O'Shaughnessy a Hennenberg 2007: 254-257). Za předpokladu, že politické značky působí v horizontu spotř̌ebitelské paměti stejně jako ostatní značky, nebudou mít všechny asociace stejný význam. Ve skutečnosti se asociace se značkou liší v jejich relativní síle a jedinečnosti (Keller 1993: 2). Nevyhnutelně platí, že čím více pozitivní (negativní) tyto asociace jsou, tím silnější (slabší) bude značka pro voliče. Např́klad když je strana spojována s jasně vymezenou pozicí v konkrétní oblasti, která je voličem považována za důležitou, pak tato oblast bude silným elementem značky. Konkurenčně nezbytné pro univerzální strany se však ukazuje 
posouvání do pozice politického středu. V současné době jsou programy politických stran velmi podobné konsensu existujícímu v klíčových otázkách (policies). Díky tomu se může stát, že bude politika (policy) vnímána jako méně unikátní rozlišující znak, a tedy slabší prvek značky. Dokonce v případech, kdy jedinečná politika (policies) v poslední době existovala, nebyla viděna jako důležitý prvek nebo nebyla pozitivně přijata - jako př́klad můžeme uvést britské konzervativce s jejich euro-skeptickým postojem vůči imigraci ve volbách 2001 a 2005 (Smith a French 2009: 212).

Etablování stran jako značek v myslích voličů může strany značně posílit, protože politické značky nabízejí voličům prvky soudržnosti, známosti a předvídatelnosti (Singer 2002). Ve spojení s tím mohou mít značky stran podobu signálů směrem k voličům, které jsou jednoduché, důvěryhodné, charakteristické a kontinuální (Tomz a Sinderman 2005: 17-20). Např́iklad u britské Labouristické strany je dlouhodobou klíčovou hodnotou značky snížení nerovnosti a podpora sociální spravedlnosti, u Konzervativní strany je to prosazování jedince a nižších daní. Jádrové významy jsou užitečné pro voliče, kteří se je po jejich osvojení již nemusí znovu učit. Je zajímavé, že ačkoliv se hlavní strany ve Spojeném království přemístily v rámci politického trhu (Labouristická strana za Tonyho Blaira a Konzervativní strana za Davida Camerona), klíčové hodnoty jejich značek zůstaly neměnné. Politické strany tak narozdíl od většiny komerčních značek spíše než radikální změnou svých významů prochází postupnou evolucí. Je zřejmé, že síla stranické značky není neměnná. Pokud strana začne působit nejednotně nebo vysílá protichůdné zprávy voličům, dojde k narušení jejího vnímání jako soudržné značky a ke ztrátě důvěryhodnosti - voliči z principu nechtějí podpořit rozpolcené strany (Smith a French 2009: 213).

Důležitým pravidlem v rámci teorie politické značky je, že lídr strany má často silněji působící asociativní význam. Jeho image je snadněji identifikovatelná a sdělitelná prostřednictvím verbální a vizuální představivosti (Schneider 2004: 44-49). Vnímání obrazu lídra je samožrejmě v politice často nekontrolovatelné. Když byly obrazy politických lídrů (příznivé i neprŕíznivé) měřeny za pomoci škály osobnosti značky podle Jennifer Aaker, jejíž model bude představen níže v textu, byl například Gordon Brown veřejností vnímán jako zarputilý, zatímco David Cameron představoval v očích veřejnosti mladého a svěžího politika. Při testování ve Velké Británii bylo zjištěno, že voliči mají silné a konzistentní názory na osobnosti lídrů politických stran (Smith-French 2009: 213). Na první pohled se zdá, že lídr je důležitý, nebot' dochází k přenosu jeho asociací na značku. Například jmenování Davida Camerona za lídra Konzervativní strany se shodovalo se zvýšením popularity strany. Teorie důvěryhodnosti poskytuje vysvětlení, jak může lídr podpořit vnímáním své osobnosti značku celé strany. Tato teorie, která původně sloužila $\mathrm{k}$ vysvětlování efektu podpory veřejně známých osobností (celebrity endorsement effect), naznačuje, že přenos zpráv (a obrazu) je ovlivněn důvěryhodností a odborností zdroje (Smith-French 2009: 213). Zároveň bylo zjištěno, že i atraktivita viditelně ovlivňuje důvěryhodnost značek obecně a v oblasti politiky zejména (Ohanian 1990: 44).

Celkově tedy můžeme shrnout, že tři klíčové elementy politických značek jsou v myslích voličů neoddělitelné. Kromě toho se bude jejich relativní význam, pokud jde o celkové vnímání značky, lišit v závislosti na charakteru politického trhu, důvěryhodnosti, přitažlivosti a osobnosti lídrů politických stran a na vnímání strany z pohledu její důvěryhodnosti 
při plnění slibů. Kumulativní účinek těchto tř̌i klíčových asociací má př́imý dopad na celkové voličské hodnocení politických značek a na rozhodnutí voličů, jak budou hlasovat ve volbách (Smith-French 2009: 214).

\section{Osobnost značky}

Důležitou součástí značky je její osobnost (brand personality). Osobnost značky lze definovat jako sadu lidských charakteristik obecně spojených se značkou (Keller 1993: 3-4, nebo Aaker 2003: 123). Osobnost značky politické strany je vnímaná jako asociativní sít’ lidských charakteristik vztahujících se k této straně. Charakteristiky jsou zakotveny v paměti a př́stupné v okamžiku, kdy je pamět’ voliče stimulována. Počet potenciálních zdrojů, z nichž se může rozvinout znalost osobnosti značky, je enormní (Aaker 1997: 347).

Vlastnosti osobnosti jsou utvořeny v paměti na základě sledování (pozorování) chování ostatních osob. Budování osobnosti značky se tak stává důležitou součástí úspěchu (a to nejen v politice), protože pomáhá zvyšovat transparentnost, případně snižovat nejistotu a „strach z neznámého“. Značka v tomto případě komunikuje za nás, at’ už se jedná o postoje, dovednosti či talent. Správná informovanost a image mohou být nedocenitelné, nebot' ovlivňují způsob, jakým s námi jednají jiní lidé, jak interpretují naše slova, činy a jednání (Plummer 1984: 30). Když někdo např́íklad bude kopat do psa, lze dovodit, že je krutý.

Utváření osobnosti značky je determinováno stejným procesem jako lidská osobnost. Jedná se o personifikaci značky na základě pozorování chování jejích představitelů. Vlastnosti značky se tedy dají odvodit z akcí nebo proklamovaných zamýšlených opatření (Smith a French 2009: 214). Politické strany a politici mohou být popsáni jako zřetelné osobnosti. Pokud je lídr silnou osobností, která je schopna ztělesňovat řadu vlastností, je pro voliče snadnější učit se jeho osobnostní rysy, než je tomu u neživého subjektu, jako například u politické strany.

To může být vysvětlováno i tak, že politika je stále více o symbolismu v protikladu k uskutečňování politik (policy), o image spíše než o obsahu. Politici pak mohou být vnímáni jako „herci“, kteří cíleně hrají způsobem napomáhajícím dosažení cílů předem stanovených politickou stranou (O'Shaughnessy 2003). Takto vystupoval např́íklad David Cameron, který před volbami v roce 2010 zdůrazňoval svou dynamičnost a modernost tím, že cestoval do práce na kole, používal iPod, neváhal být spojován s fair-trade produkty a před dům si instaloval větrnou turbínu. Všechny tyto projevy chování mají ilustrovat rysy osobnosti relevantní pro volbu strany/lídra. Jejich účelem je ilustrovat spíše politickou značku než skutečnou osobnost politika.

Pro voliče osobnost strany a její politici nepředstavují dva oddělené nesvázané celky, ale naopak tvoří uvnitř voličské paměti asociativní sít' vypovídající o celkové značce, jako je tomu v případě korporátních a produktových značek, které se v ideálním případě vzájemně posilují a pozitivně doplňují (Smith a French 2009: 215). Také chování stran v minulosti produkuje jistý druh dědictví značky, který se promítá do celkové paměti o značce.

I aktuální politiky mohou mít vliv na vnímání osobnosti značky. Například aktuální nebo navrhovaná opatření proti trestné činnosti či korupci mohou stranu stylizovat tak, že je vnímána jako tvrdá a rozhodná. Rozhodnutí britských konzervativců (které prosadil jejich 
volební stratég Lynton Crosby) zaměřit se v roce 2005 v rámci volební kampaně na romskou otázku a imigraci na jedné straně konsolidovalo hlasy jejich pevného voličského jádra, ale zároveň stimulovalo vazby $\mathrm{v}$ paměti ostatních, pro které se konzervativní strana ve vnímání zařadila jako „odporná“ strana (Smith a French 2009: 215).

\section{Jak měřit osobnost značky}

Zjistit, jak voliči (spotřebitelé) vnímají osobnost značky, lze dvěma způsoby. Můžeme použít kvalitativní techniky a např́klad za pomoci hloubkových rozhovorů odhalit názory spotřebitelů na osobnost značky. Kvalitativní postupy poskytují řadu zajímavých poznatků a informací o osobnosti značky, jejich problém spočívá ve skutečnosti, že je nezbytné je provádět pokaždé, když je nutný projekt osobnosti značky, a zároveň v jejich značné časové náročnosti. Pokud se následně vytvoří hodnoticí stupnice, lze ji obvykle použít pouze pro tu značku (nebo jen malou skupinu značek), která byla součástí původního projektu (výzkumu). $\mathrm{Z}$ tohoto důvodu je problematické měřit mezi voliči (spotřebiteli) měnící se vnímání většího počtu značek v průběhu času. Podobné sledování a komparace vyžaduje obecně použitelnou škálu, která by byla spolehlivá a platná. Zř̉ejmě nejpropracovanější škálu tohoto typu vytvořila Jennifer Aaker (1997), která ve své práci tvrdí, že vytvořila spolehlivou, platnou a obecně použitelnou hodnoticí stupnici osobnosti značky.

Aaker nejdříve provedla obsáhlou analýzu odborné literatury a kvalitativních výzkumů, v jejímž rámci identifikovala 309 různých osobnostních znaků. Následně provedla redukci těchto znaků za pomoci skupiny 25 lidí, kteří měli hodnotit, jak dobře popisuje 309 vybraných znaků značky obecně. $Z$ tohoto hodnocení vyplynulo 114 znaků, které respondenti považovali za znaky popisující osobnost značek. Do spotřebitelské studie, která hodnotila vybrané značky, bylo zahrnuto 131 značek z 39 kategorií produktů a služeb. Ze statistické analýzy vyplynulo, že vybrané značky reprezentují devět skupin osobnostních profilů. Následně byly z každé skupiny vybrány čtyři značky, aby se prověřilo vhodné rozdělení symbolických a užitkových kategorií. Celkově bylo nakonec vybráno 37 značek² (de Chernatony 2009: 244).

Z následného šetření na reprezentativním vzorku americké populace vyplynulo pětidimenzionální řešení, které pokrývalo $92 \%$ rozptylu osobnosti značky. Obecná platnost pěti dimenzí osobnosti značky byla prověřena provedením analýzy hlavních komponent u dílčích vzorků a bylo dosaženo přijatelné úrovně podobnosti. K identifikaci znaků (indikátorů), které tvoří každou z pěti dimenzí osobnosti (Aaker je pojmenovala: upřímnost, vzrušení, kompetentnost, náročnost a odolnost), byly pro sady znaků (indikátorů) u každého faktoru provedeny samostatné faktorové analýzy (de Chernatony 2009: 244-245). Výsledky kontrolní

2 Některé z 37 značek, které byly využity v rámci výzkumu, pokrývají širokou škálu spotřebitelských značek, některé služby (VISA, CNN), některé komplexy značek vyžadující rozšsiřrené rozhodování (Apple a IBM, Mercedes), další pak brandy rychloobrátkového zboži (Pepsi-Cola, McDonalds) (French-Smith 2009: 218). 
studie ukázaly vysokou úroveň shody pro pět dimenzí osobnosti, což posílilo důvěru v obecnou použitelnost modelu. ${ }^{3}$

Přesto se v následném období objevili kritici, kteří vznesli pochybnosti ohledně obecné aplikovatelnosti modelu. Např́íklad Azoulay a Kapferer upozorňují na skutečnost, že škála osobnosti spojuje řadu dimenzí osobnosti značky (2003: 152). Austin a kol. (2003) po provedení dalších dílčích studií vypozorovali, že se tato soustava nevztahuje na některé značky, které byly součástí původního výzkumu Jennifer Aaker. Podle jejich soudu soustava měření osobnosti negeneralizuje situace, $v$ nichž je osobnost měřena na úrovni individuální značky. Podle nich je pak jedním z důvodů interakce mezi značkami a interpretacemi osobnostních znaků u respondentů. Např́íklad rys, který je označen jako „,cool“ (anglicky „chladný“, ale i hovorově „skvělýc), může evokovat na jedné straně něco, co je „in“, případně ,,v kurzu“, ale u jiných značek (například v případě služeb) může vyvolávat představu chladného, nepřátelského personálu (de Chernatony 2009: 246).

\section{Jak měřit osobnost značky $v$ rámci politického pole}

Vzhledem k tomu, že politické značky se liší od jiných značek, nelze zcela převzít strukturu osobnosti značek a použít ji na politické pole. V rámci výzkumu politických značek byla škála testována např́iklad Garethem Smithem. Jeho výzkum se orientoval pouze na otestování původní škály Jennifer Aaker, kterou aplikoval na skupinu 183 studentů. Jak sám uvádí, nejednalo se o reprezentativní vzorek, ale o relativně homogenní skupinu (z hlediska věku, pohlaví, vzdělání), která byla vhodná pro testování škály (Smith 2009: 219). Na základě tohoto výzkumu byla vytvořena modifikovaná škála určená pro výzkum osobnosti politických značek. Tato škála se skládá z šesti dimenzí, které mají v součtu 34 indikátorů.

Smith nejprve použil původní škálu, kterou vytvořila Aaker, a použil ji na politické pole ve Spojeném království (Smith 2009: 220). Vzhledem ke skutečnosti, že se politické značky liší od jiných značek, nešlo automaticky předpokládat, jak upozorňuje Smith, že bude škála plně aplikovatelná pro politický trh (politické pole).

Před samotnou distribucí dotazníku provedl Smith dva předběžné testy, aby zjistil, zda osobnostní znaky (indikátory) jsou vhodné pro jím zvolenou oblast zkoumání, tedy britské politické pole. Prvním testem bylo posouzení škály třemi akademiky, kteří disponovali hlubokými znalostmi o daném poli. Následný druhý test spočíval v předložení škály vzorku sestávajícímu z osmi vybraných studentů. Předběžné testy odhalily některé znaky (indikátory, konkrétně „západni'“ a „maloměstský“) jako matoucí v britském kontextu, a následně byly tyto osobnostní znaky z dotazníku odstraněny. Po dokončení testování byl dotazník distribuován studentům bakalářského studijního programu podnikání s cílem zjistit, zda lze škálu použít pro (britské) politické strany. Byla provedena faktorová analýza za použití analýzy hlavních komponent (Smith 2009: 226). Výsledky ukázaly, že pětidimenzionální model vysvětloval pouhých 53 \% rozptylu, což je dosti nízká hodnota (Smith 2009: 220).

3 Pro ověření, zda těchto pět dimenzí nebylo pouze výsledkem jedné konkrétní skupiny značek nebo konkrétního vzorku osob, byla provedena kontrolní studie s novým vzorkem respondentů (180), kteří pomocí 42 osobnostních znaků hodnotili odlišný soubor značek. 
Také deset osobnostních znaků (indikátorů) rozložených v jednotlivých dimenzích se lišilo od modelu Jennifer Aaker. Smith proto zavrhl pětidimenzionální model a nahradil ho šestidimenzionálním modelem, kdy přidal novou dimenzi ,jedinečnost“. Zároveň, jak již bylo zmíněno, se některé osobnostní znaky (indikátory) v rámci faktorové analýzy ocitly v jiných dimenzích než v rámci původního modelu, $\mathrm{z}$ tohoto důvodu došlo ke změně názvů všech dimenzí, aby lépe vystihovaly nové tematické okruhy v rámci modifikované škály pro (britské) politické strany (Smith 2009: 220-221).

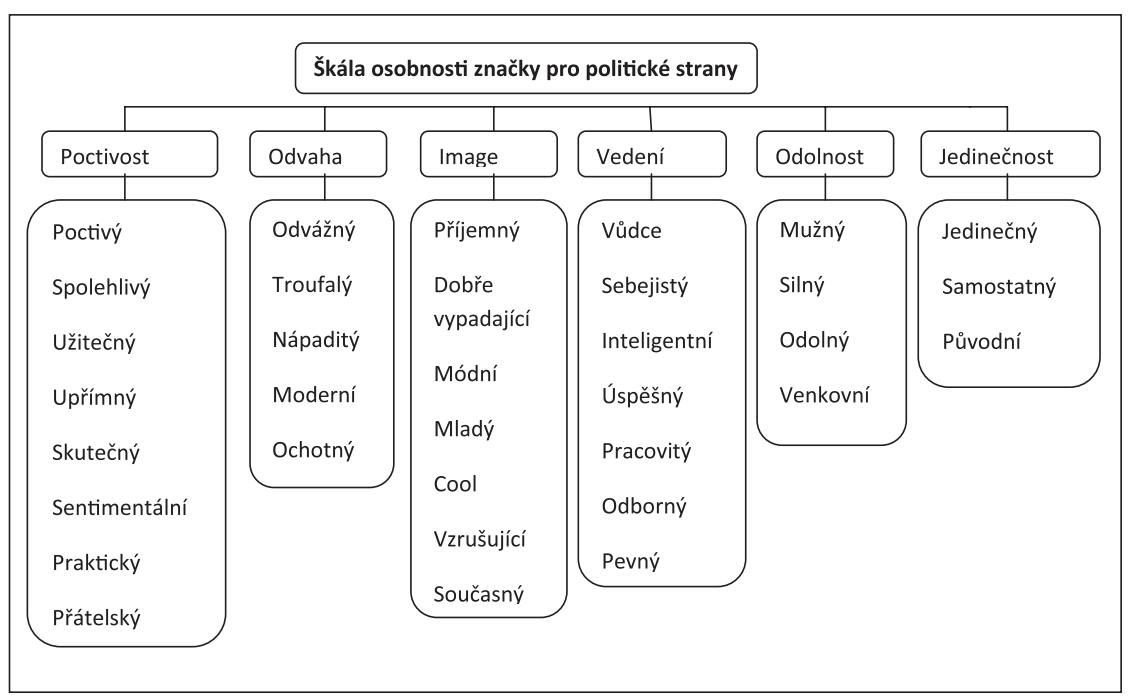

Obrázek 1: Škála osobnosti značky pro politické strany (Smith 2009)

\section{Případová studie: Osobnosti značek českých politických stran}

$\mathrm{Na}$ základě představené teorie a popsaných konceptů byly v rámci našeho výzkumu vymezeny následující výzkumné otázky:

1. Jak jsou vnímány osobnosti značky jednotlivých stran v České republice?

2. Existuje respondenty jednotně sdílené povědomí o značkách českých politických stran?

3. Je možné využít $\mathrm{v}$ českém prostředí podobné dimenze škály osobnosti značky jako v původní studii?

4. Jak ovlivňují vnímání značek stran stranické sympatie?

První výzkumná otázka má zřetelně explorativní charakter; využívá toho, že podobná studie (pokud je nám známo) zatím v českém prostředí nevznikla. Její zodpovězení má přinést nové informace o osobnosti značky hlavních českých politických stran. Zbývající otázky mají teoretický základ a jejich zodpovězení má usnadnit další práci s konceptem vnímání značek v českém prostředí. Druhá z nich se zajímá o to, nakolik je vůbec realistické předpokládat, že úsilí stran etablovat osobnosti svých značek vede k tomu, že respondenti tyto strany 
vnímají - ve velké míře - jednotně. S tímto předpokladem souvisí i čtvrtá otázka, zkoumající rozdíly mezi sympatizanty stran a ostatními respondenty. Zde se dotýkáme často citovaného názoru, že strany cílí své aktivity zejména na své př́iznivce (Cox-McCubbins 1986), případně nerozhodnuté voliče (například Stokes 2005), zatímco ostatní voliče vynechávají. A konečně tř̌etí otázka se snaží prověřit, zda je možné i v českém prŕípadě sloučit jednotlivé dílčí vlastnosti do škál, s nimiž pracovala britská studie.

Osobnost značky byla součástí širšího výzkumu vnímání českých politických značek, který proběhl od 28. února do 28. března 2011 na vybraných českých gymnáziích ve 13 krajích České republiky (jediným nezastoupeným krajem byl Královéhradecký kraj) a rovnoměrně pokrýval poslední čtyři gymnaziální ročníky. ${ }^{4}$ Celkem se výzkumu zúčastnilo 564 studentů a výzkumný vzorek tvořilo 336 žen (59,6 \%), 222 mužů (39,4 \%), šest respondentů neuvedlo své pohlaví. Výzkum zjišt'oval vnímání osobnosti značky pro sedm vybraných českých stran (ODS, ČSSD, TOP 09, VV, KSČM, SZ a KDU-ČSL).

Respondenti měli nejprve $\mathrm{v}$ oddíle „osobnost značky“ vyjádřit, nakolik osobnostní znaky popsané ve výzkumu G. Smithe (2009: 220) vystihují osobnost značek vybraných politických stran. Dotazník byl distribuován v sedmi různých variantách, kdy v každé variantě byla obsažena škála pro jednu ze sedmi sledovaných stran. Respondenti byli instruováni, že si mají představit určenou stranu jako skutečnou osobu s různými povahovými vlastnostmi. Následně byli požádáni, aby popsané vlastnosti obodovali za použití pětibodové škály, ve které číslo 1 značilo, že daná vlastnost osobnost značky naprosto necharakterizuje, zatímco číslo 5 vyznačovalo, že dané adjektivum osobnost značky zcela charakterizuje.

$\mathrm{V}$ rámci výzkumu byly zároveň zjišt'ovány celkové sympatie respondentů vůči sledovaným stranám. Respondenti byli dotazováni, jaký je jejich celkový postoj ke sledovaným stranám. Na základě jejich odpovědí bylo možné rozdělit respondenty na dvě skupiny. První skupinu lze označit jako příznivce; tvoří ji respondenti, kteří vyjádřili kladný či neutrální postoj. Druhou skupinu pak tvoří odpůrci, tedy respondenti, kteří vyjádřili vůči straně negativní postoj. Sympatie respondentů ${ }^{5}$ vůči straně se následně staly důležitou třídicí proměnnou.

\section{Vnímání osobnosti značek politických stran skupinou prvovoličů}

Vzhledem $\mathrm{k}$ tomu, že výsledné hodnoty v rámci škály jsou prezentovány jako průměry a jsou mezi sebou následně porovnávány, je nutné informace o průměru doplnit informacemi o variabilitě hodnot jednotlivých indikátorů. Proto je u všech dále prezentovaných průměrů

4 Gymnázia byla zvolena záměrně, protože se jedná o typ školy, která má podobný profil ve všech krajích. Gymnázia byla vybrána na základě dostupnosti kvótním výběrem, respondenti pak podle jednotlivých krajů a ročníků. Kvóty byly nastaveny tak, aby výzkum pokryl všech 14 krajů ČR. V rámci sběru dat došlo ke komplikacím se sběrem v Královéhradeckém kraji, a nakonec nebylo možné data sebrat. $V$ posledních čtyřech ročnících gymnázií jsou studenti ve věku 15 až 20 let, kteří bud' byli prvovoliči v posledních volbách, případně se jimi stanou nejdéle v prř́štích parlamentních volbách.

5 Respondenti se deklarovali následovně: ODS 60 př́íznivců a 23 odpůrců, ČSSD 30 příznivců a 49 odpůrců, TOP 0963 př́znivců a 7 odpůrců, VV 48 příznivců a 23 odpůrců, KSČM 31 př́znivců a 53 odpůrců, SZ 59 př́znivců a 15 odpůrců a KDU-ČSL 57 příznivců a 15 odpůrců. 
uvedena směrodatná odchylka. Navíc směrodatná odchylka nám umožňuje výpočet variačního koeficientu, jehož hodnoty indikují, nakolik je průměr reliabilní statistikou. ${ }^{6}$

Výsledky variačního koeficientu zároveň mohou posloužit jako indikátor, který nám napovídá, nakolik je obraz značky v myslích voličů pevně zakotven. Pokud by v myslích respondenti̊ existoval ucelený obraz značky politických stran, měly by jejich odpovědi být relativně homogenně rozloženy a výsledné hodnoty variačního koeficientu by měly být nízké.

Hodnoty variačních koeficientů jsou však u jednotlivých znaků u všech stran značně vysoké: prakticky všechny dosahují výsledků vyšších než 40 \%, proto by neměl být výsledným průměrům přisuzován zvláštní význam. Výsledná data, která jsou uvedena $\mathrm{v}$ grafech dále v textu, tak představují spíše nástin vnímání jednotlivých stran a při jejich interpretaci je vždy potřeba přihlédnout $\mathrm{k}$ hodnotě směrodatné odchylky nebo variačního koeficientu. ${ }^{7}$

Tabulka 1: Hodnoty variačního koeficientu pro jednotlivé sledované osobnostní znaky

\begin{tabular}{|l|l|l|l|l|l|c|c|}
\hline & ODS & ČSSD & TOP 09 & VV & KSČM & SZ & KDU-ČSL \\
\hline Poctivý & 44,55 & 53,7 & 42,35 & 48,11 & 53,7 & 40,26 & 41,01 \\
\hline Spolehlivý & 44,97 & 52,01 & 40,65 & 45,09 & 52,01 & 39,03 & 35,58 \\
\hline Užitečný & 43,79 & 51,9 & 39,09 & 47,42 & 51,9 & 42,15 & 47,13 \\
\hline Upř́mný & 51,24 & 62,3 & 43,64 & 48,7 & 62,3 & 42,73 & 42,35 \\
\hline Skutečný & 43,12 & 52,81 & 39,6 & 40,5 & 52,81 & 43,71 & 41,87 \\
\hline Sentimentální & 47,31 & 42,9 & 48,81 & 47,3 & 42,9 & 46,9 & 45,12 \\
\hline Př́telský & 38,9 & 51,18 & 42,82 & 42,63 & 51,18 & 40,05 & 42,53 \\
\hline Praktický & 40,26 & 50,28 & 40,35 & 42,15 & 50,28 & 41,08 & 42,96 \\
\hline Odvážný & 39,72 & 47,57 & 37,53 & 41,17 & 47,57 & 44,38 & 58,61 \\
\hline Troufalý & 31,72 & 40,65 & 42,33 & 37,05 & 40,65 & 48,35 & 61,75 \\
\hline Nápaditý & 43,32 & 45,92 & 39,25 & 42,3 & 45,92 & 43,37 & 55,17 \\
\hline Moderní & 38,59 & 57,82 & 42,79 & 43,63 & 57,82 & 40,03 & 55,86 \\
\hline
\end{tabular}

6 Běžně je uváděno, že pokud hodnota variačního koeficientu dosahuje hodnot do $10 \%$, svědčí to o nízké míře variability, a aritmetický průměr je tak možné považovat za typickou hodnotu v rámci datového souboru a má silnou vypovídající hodnotu. Oproti tomu hodnoty do $40 \%$ svědčí o vyšší variabilitě a hodnota aritmetického průměru je pak spíše orientačním údajem. Pokud variační koeficient dosahuje vyšších hodnot, není dobré dávat aritmetickému průměru zvláštní význam, protože se zřejmě nejedná o typickou hodnotu datového souboru.

$7 \quad$ Níže $v$ textu je $\mathrm{v}$ grafech vždy uvedena spolu s průměrem standardní odchylka, kterou bylo $\mathrm{v}$ grafech výhodnější zmínit díky skutečnosti, že může být prezentována ve stejných jednotkách jako průměr. Při samotném popisu je pak využíván variační koeficient, který se vypočítá jako poměr směrodatné odchylky $\mathrm{k}$ aritmetickému průměru násobený 100 . Jeho výsledek je v procentech a je tak snadnější na interpretaci.

$8 \quad$ V tabulce jsou zvýrazněny hodnoty variačních koeficientů, které jsou nižšíi než 40 \%. Výsledné hodnoty průměrů u daných znaků mohou být interpretovány jako orientační. 


\begin{tabular}{|c|c|c|c|c|c|c|c|}
\hline & ODS & ČSSD & TOP 09 & VV & KSČM & SZ & KDU-ČSL \\
\hline Ochotný & 42,72 & 52,88 & 40,24 & 41,48 & 52,88 & 39,18 & 42,68 \\
\hline Př́jemný & 44,35 & 56,55 & 46,64 & 45,08 & 56,55 & 41,52 & 42,07 \\
\hline $\begin{array}{l}\text { Dobře } \\
\text { vypadající }\end{array}$ & 49,56 & 60,3 & 48,1 & 46,2 & 60,3 & 44,51 & 56,53 \\
\hline Módní & 55,97 & 65,43 & 55,27 & 49,93 & 65,43 & 44,56 & 63,3 \\
\hline Mladý & 52,69 & 60,05 & 55,63 & 44,99 & 60,05 & 40,73 & 66,12 \\
\hline Cool & 61,33 & 56,09 & 56,84 & 50,35 & 56,09 & 50,34 & 76,21 \\
\hline Vzrušující & 60,49 & 58,49 & 57,59 & 60,52 & 58,49 & 59,59 & 65,69 \\
\hline Současný & 34,94 & 49,94 & 31,09 & 33,45 & 49,94 & 36,78 & 50,44 \\
\hline Vůdce & 39,23 & 51,52 & 41,06 & 46,64 & 51,52 & 53,11 & 56,21 \\
\hline Sebejistý & 25,44 & 35,4 & 34,15 & 35,84 & 35,4 & 43,73 & 44,17 \\
\hline Inteligentní & 45,24 & 43,75 & 40,82 & 41,38 & 43,75 & 40,96 & 35,41 \\
\hline Úspěšný & 36,58 & 39,8 & 35,67 & 32 & 39,8 & 43,38 & 44,95 \\
\hline Pracovitý & 42,32 & 54,51 & 35,42 & 41,62 & 54,51 & 36,93 & 38,41 \\
\hline Odborný & 41,83 & 49,22 & 39,57 & 45,13 & 49,22 & 37,91 & 42,35 \\
\hline Pevný & 37,58 & 53,49 & 34,74 & 42,54 & 53,49 & 41,56 & 46,66 \\
\hline Mužný & 43,1 & 59,22 & 46,02 & 47,4 & 59,22 & 51,6 & 56,49 \\
\hline Silný & 37,56 & 49,33 & 41,08 & 42,46 & 49,33 & 43,63 & 50,07 \\
\hline Odolný & 35,01 & 45,69 & 38,84 & 45,15 & 45,69 & 46,2 & 48,15 \\
\hline Jedinečný & 52,39 & 60,16 & 48 & 54,49 & 60,16 & 43,96 & 54,1 \\
\hline Samostatný & 43,7 & 52,69 & 45,01 & 47,8 & 52,69 & 42,58 & 50,55 \\
\hline Pưvodní & 41,5 & 47,7 & 52,44 & 62,12 & 47,7 & 52,81 & 40,62 \\
\hline
\end{tabular}

Vysoké hodnoty variačního koeficientu naopak mohou indikovat skutečnost, že se českým politickým stranám nedaří v rámci procesu budování svých značek (je otázkou, zda existují v rámci stran ucelené strategie věnující se této oblasti) utvořit v myslích voličů (v našem případě potencionálních) obraz osobnosti značky.

Porovnáme-li výsledné hodnoty souhrnných průměrů variačních koeficientů pro popsané skupiny př́znivců a odpůrců (tabulka 2), můžeme vidět, že u skupiny, kterou jsme označili jako příznivce, jsou výsledné průměry u všech sledovaných stran nižší. Obraz značky je tedy v této skupině u všech sledovaných stran konzistentnější. Přesto jsou výsledné hodnoty souhrnných variačních koeficientů stále poměrně vysoké, což můžeme vnímat jako potvrzení teze o prozatím slabé etablovanosti konzistentního obrazu značek českých politických stran u námi sledované skupiny prvovoličů. Zároveň je však nutné upozornit na skutečnost, že u skupiny příznivců jsou výsledné průměry řádově o 10 \% nižší než u skupiny, kterou jsme označili jako odpůrce. Dané zjištění tedy poněkud problematizuje naše tvrzení, že se 
stranám nedaří budovat ucelený obraz svých značek v myslích (v našem případě) potenciálních voličů.

Tabulka 2: Souhrnné průměry variačních koeficientů - příznivci x odpưrci

\begin{tabular}{|l|c|c|c|c|c|c|c|}
\hline & ODS & ČSSD & TOP09 & VV & KSČM & SZ & KDU-ČSL \\
\hline Př́znivci & 37,82 & 45,08 & 41,51 & 39,45 & 44,72 & 42,07 & 48,22 \\
\hline Odpůrci & 56,73 & 54,45 & 52,43 & 52,7 & 54,69 & 49,71 & 53,89 \\
\hline
\end{tabular}

Následující část představuje výsledné hodnoty průměrů u jednotlivých osobnostních znaků a dále srovnání stran podle výsledných průměrů v jednotlivých dimenzích osobnosti značky.

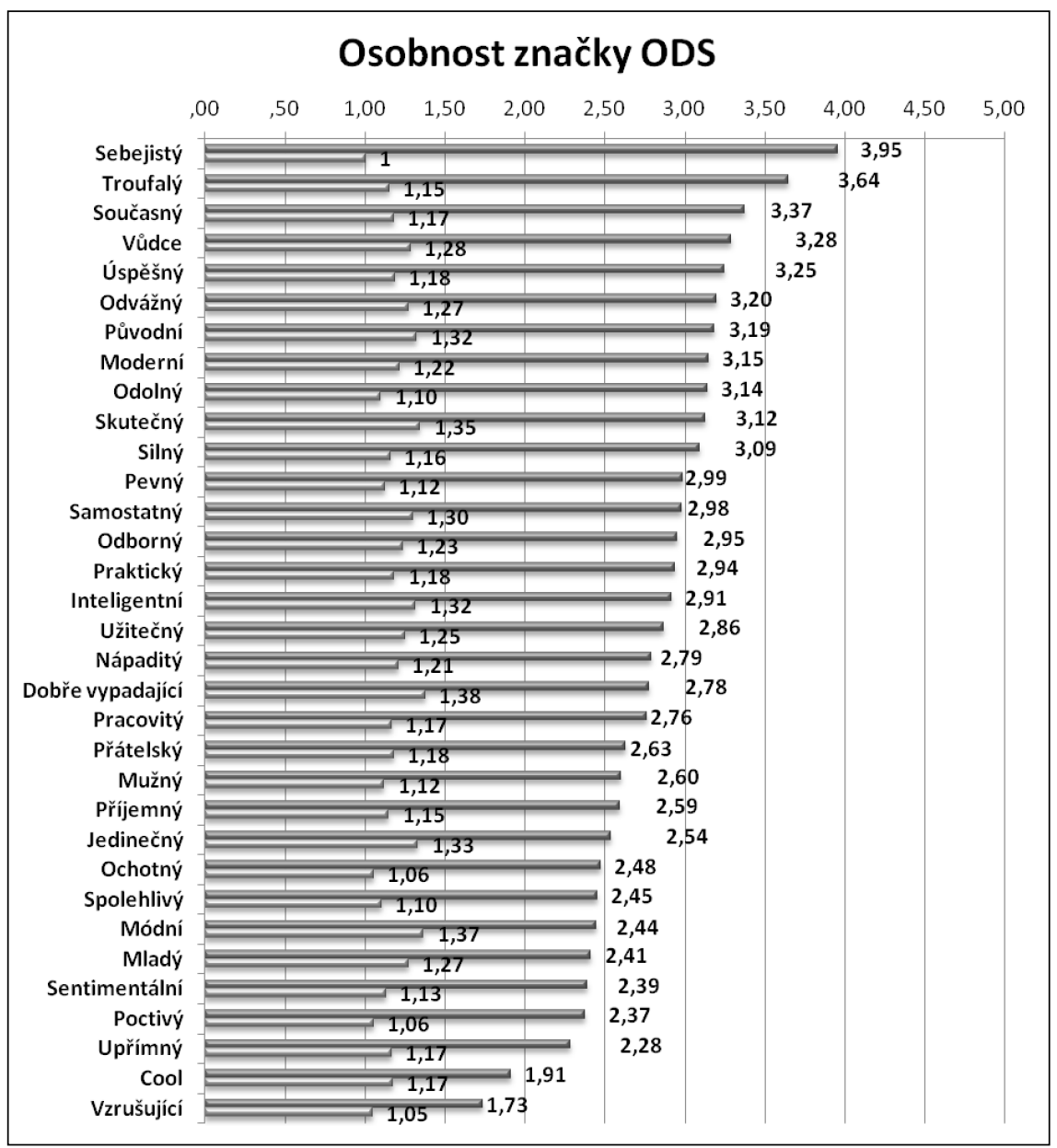

Graf 1: Osobnost značky ODS (průměry a směrodatné odchylky) 
Jak ukazuje graf 1, byla ODS nejsilněji vnímána jako sebejistá. Dosáhla hodnoty průměru 3,95 (variační koeficient dosáhl $25 \%$ ). Druhým nejsilnějším osobnostním znakem v př́ípadě ODS bylo vnímání strany jako troufalé, s průměrem 3,64 (variační koeficient $31,72 \%$ ). A konečně třetím nejsilnějším osobnostním znakem bylo vnímání ODS jako současné strany s průměrem 3,37 (variační koeficient 34,94 \%). Hodnoty variačních koeficientů u všech třech nejsilnějších osobnostních znaků dosahují nižší hodnoty než $40 \%$. Můžeme říci, že výsledné průměry mají alespoň orientační hodnotu. Nejnižších hodnot průměru pak dosahovaly osobnostní znaky upřímný (průměr 2,28 a VK 51,24 \%), cool (průměr 1,91 a VK 61,33 \%) a vzrušující (průměr 1,73 a VK 60,49 \%). V rámci výzkumu bylo sebráno celkem 84 dotazníků varianty ODS.

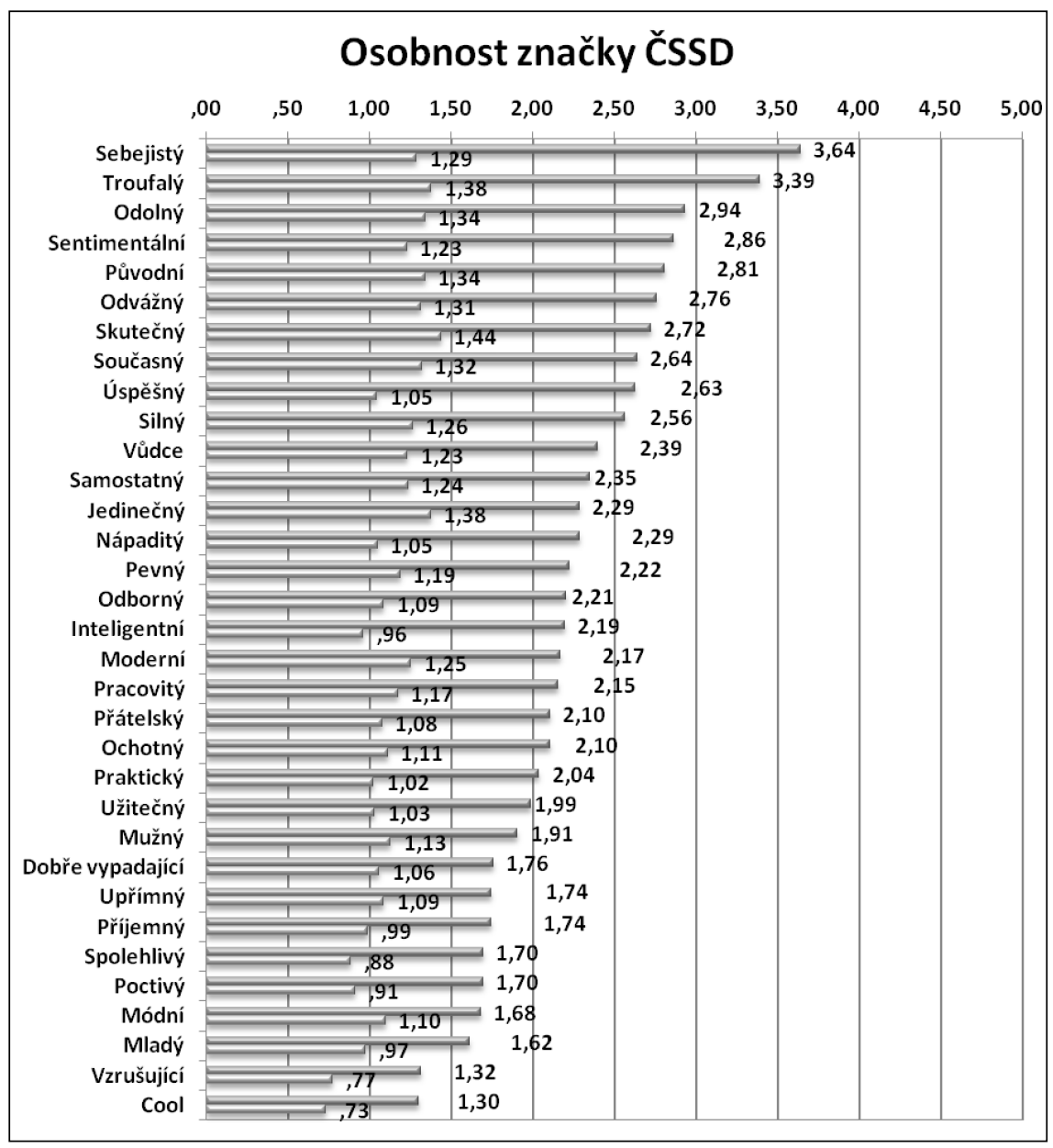

Graf 2: Osobnost značky ČSSD (průměry a směrodatné odchylky) 
ČSSD si respondenti nejsilněji spojovali s osobnostními znaky sebejistý s průměrem 3,64 (variační koeficient 35,4 \%), troufalý s průměrem 3,39 (variační koeficient 40,65 \%) a odolný s průměrem 2,94 (variační koeficient 45,69 \%). Slabě je pak ČSSD vnímána jako mladá s průměrem 1,62 (variační koeficient $60,05 \%$ ), vzrušující s průměrem 1,32 (variační koeficient 58,49 \%) a cool s průměrem 1,3 (variační koeficient 56,09 \%). V rámci výzkumu bylo sebráno celkem 82 dotazníků varianty ČSSD.

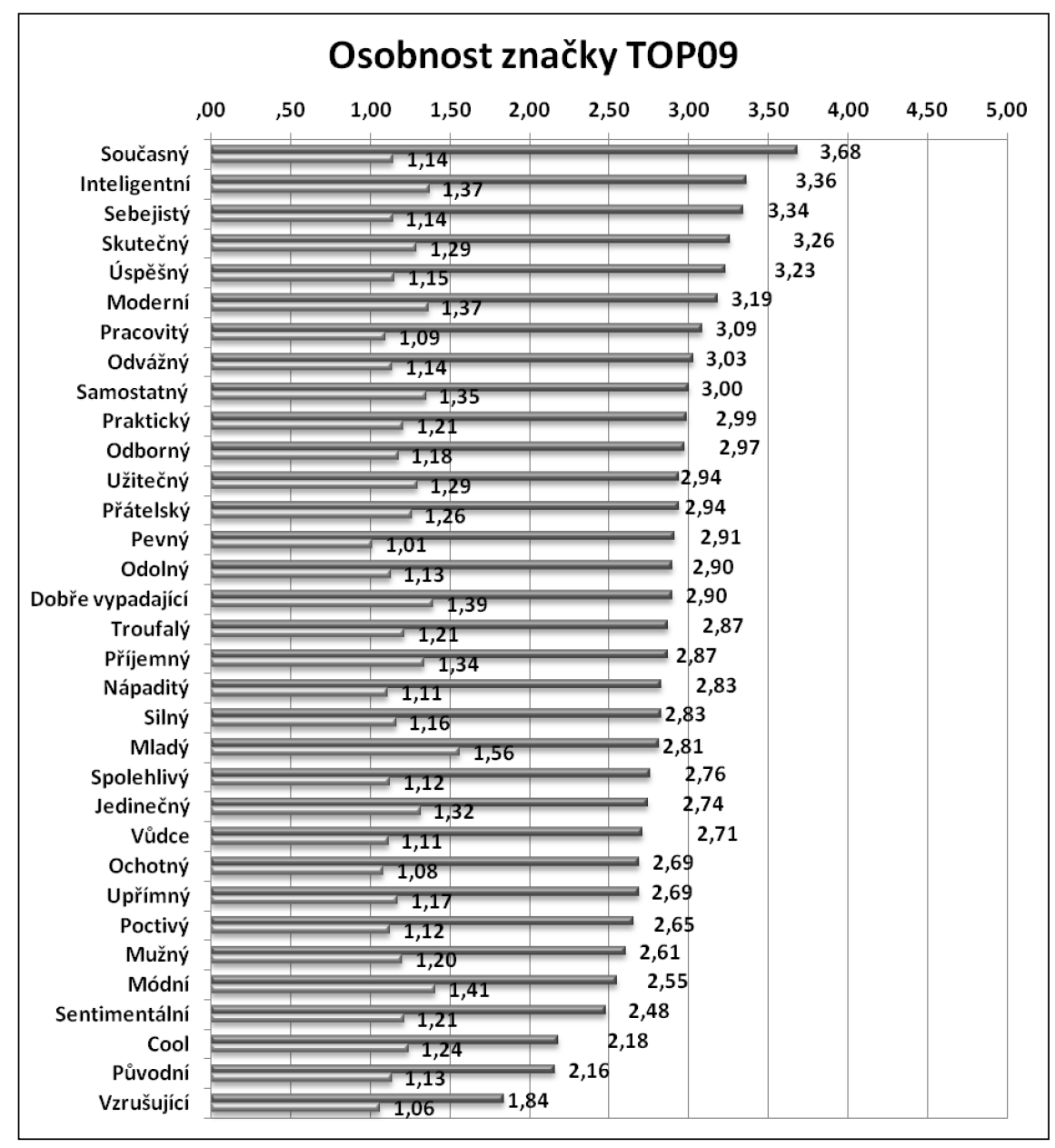

Graf 3: Osobnost značky TOP 09 (prưměry a směrodatné odchylky)

Jak je na první pohled z grafu zřejmé, respondenti vnímali TOP 09 nejvíce jako současnou s průměrem 3,68 (variační koeficient 31,09 \%), inteligentní s průměrem 3,36 (variační koeficient 40,82 \%) a sebejistou s průměrem 3,34 (variační koeficient 34,15\%) stranu. 
Nejnižších hodnot pak TOP 09 dosahovala v indikátorech cool (průměr 2,18 a variační koeficient 56,84 \%), původní (průměr 2,16 a variační koeficient 52,44 \%), vzrušující (průměr 1,84 a variační koeficient $57,59 \%$ ). V rámci výzkumu bylo sebráno celkem 74 dotazníků varianty TOP 09.

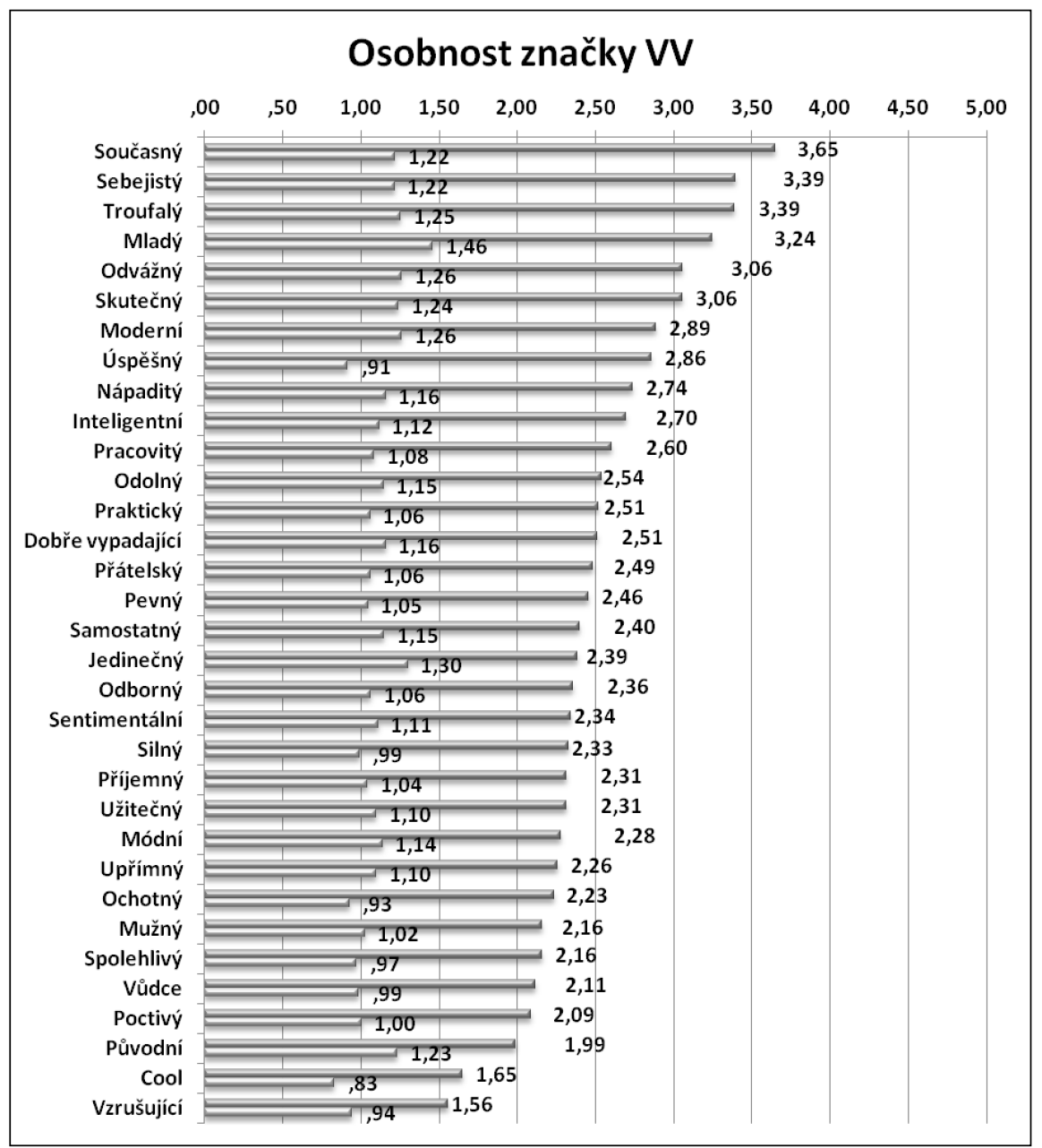

Graf 4: Osobnost značky (průměry a směrodatné odchylky)

VV byly nejsilněji spojovány se znaky současný s průměrem 3,65 (variační koeficient $33,45 \%$ ), sebejistý s průměrem 3,39 (variační koeficient 35,84 \%) a troufalý s průměrem 3,39 (variační koeficient 37,05 \%). Naproti tomu nejnižších hodnot dosahovaly v indikátorech původní (průměr 1,99 a variační koeficient 62,12 \%), cool (průměr 1,65 a variační koeficient 50,35 \%) a vzrušující (průměr 1,56 a variační koeficient $60,52 \%$ ). Celkem bylo v rámci výzkumu sebráno 76 dotazníků varianty VV. 


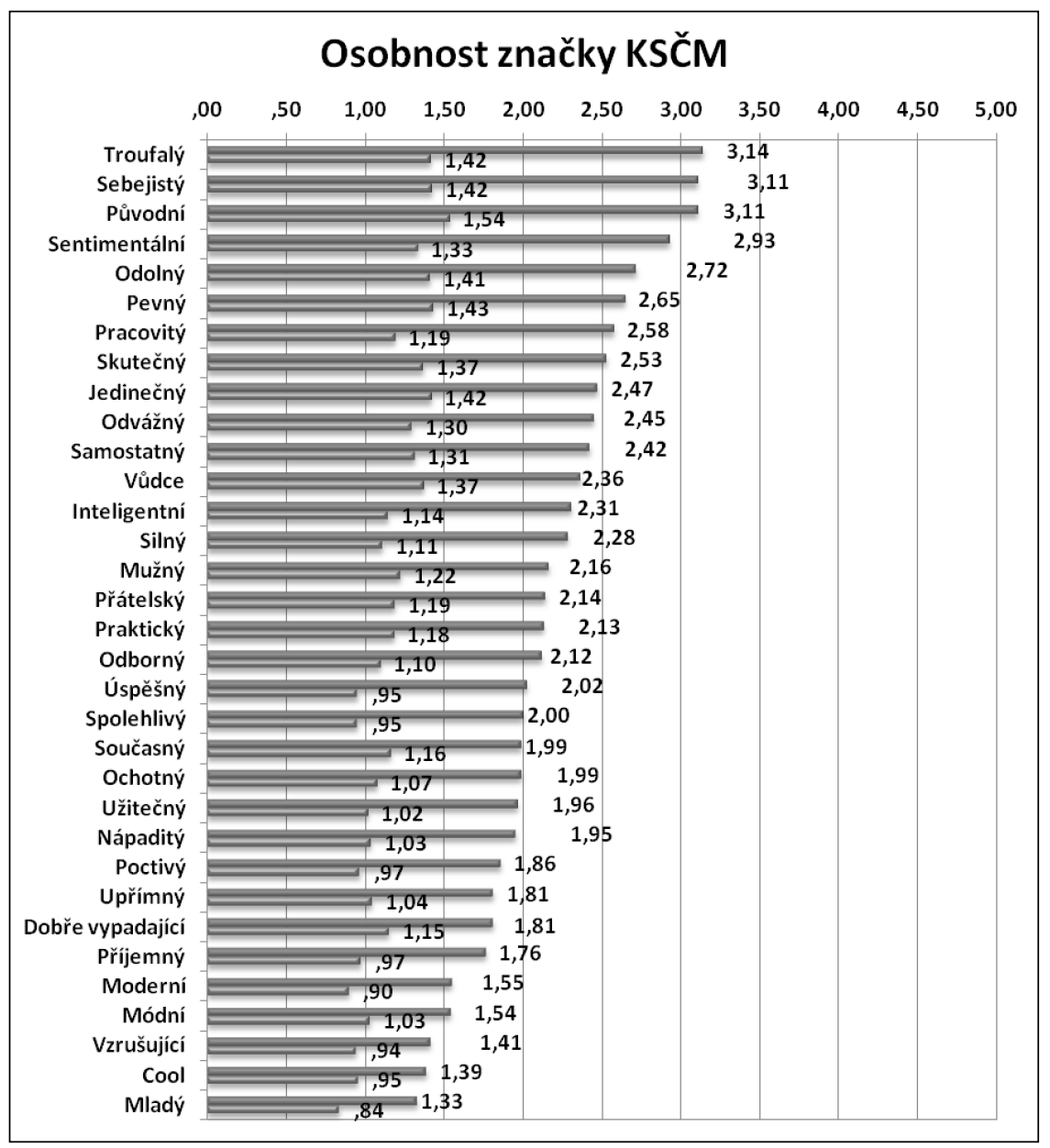

Graf 5: Osobnost značky KSČM (průměry a směrodatné odchylky)

U KSČM můžeme vidět, že strana je nejsilněji vnímaná jako troufalá s průměrem 3,14 (variační koeficient 40,65 \%) a sebejistá s průměrem 3,11 (variační koeficient 35,4 \%). Jako třetí nejsilnější osobnostní znak se v případě KSČM objevuje vnímání strany jako původní s průměrem 3,11 (variační koeficient 47,7 \%). KSČM je pak nejslaběji vnímaná jako vzrušující (průměr 1,41 a variační koeficient 58,49 \%), cool (průměr 1,39 a variační koeficient $56,09 \%$ ) a jako mladá strana (průměr 1,33 a variační koeficient $60,05 \%$ ). Celkem bylo sebráno 86 dotazníků varianty KSČM. 


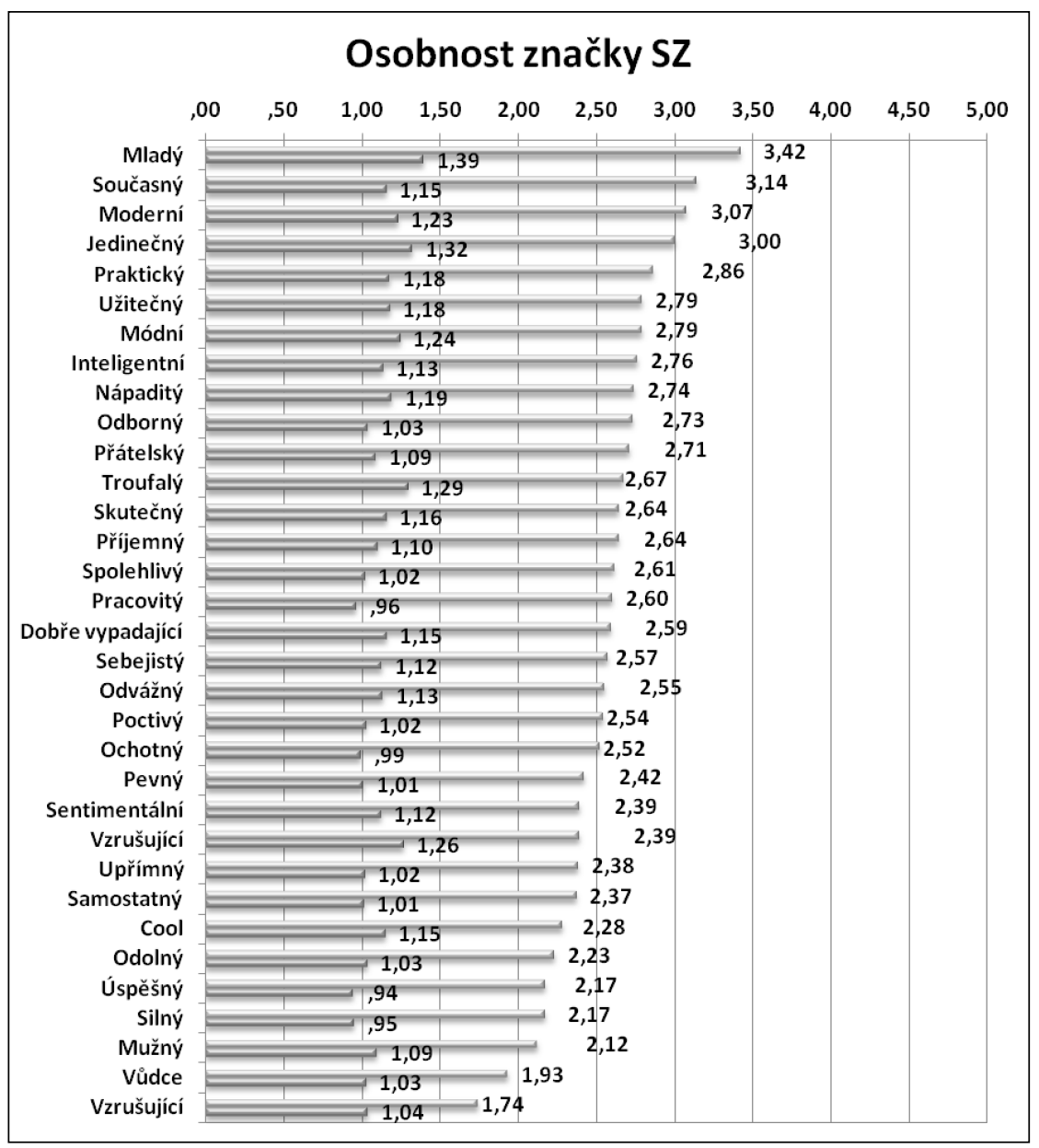

Graf 6: Osobnost značky SZ (prưměry a směrodatné odchylky)

SZ si respondenti nejvíce spojovali s osobnostními znaky mladý, kdy hodnota průměru dosáhla hodnoty 3,42 (variační koeficient 40,73 \%), současný s průměrem 3,14 (variační koeficient 36,78 \%) a moderní, kdy hodnota průměru dosáhla 3,07 (variační koeficient $40,03 \%$ ). Nejslaběji byla SZ vnímaná jako mužná (průměr 2,12 a variační koeficient 51,6 \%), vůdčí (průměr 1,93 a variační koeficient 53,11 \%) a nejméně jako vzrušující (průměr 1,74 a variační koeficient 59,59\%). Celkem bylo v rámci výzkumu sebráno 81 dotazníků varianty $\mathrm{SZ}$. 


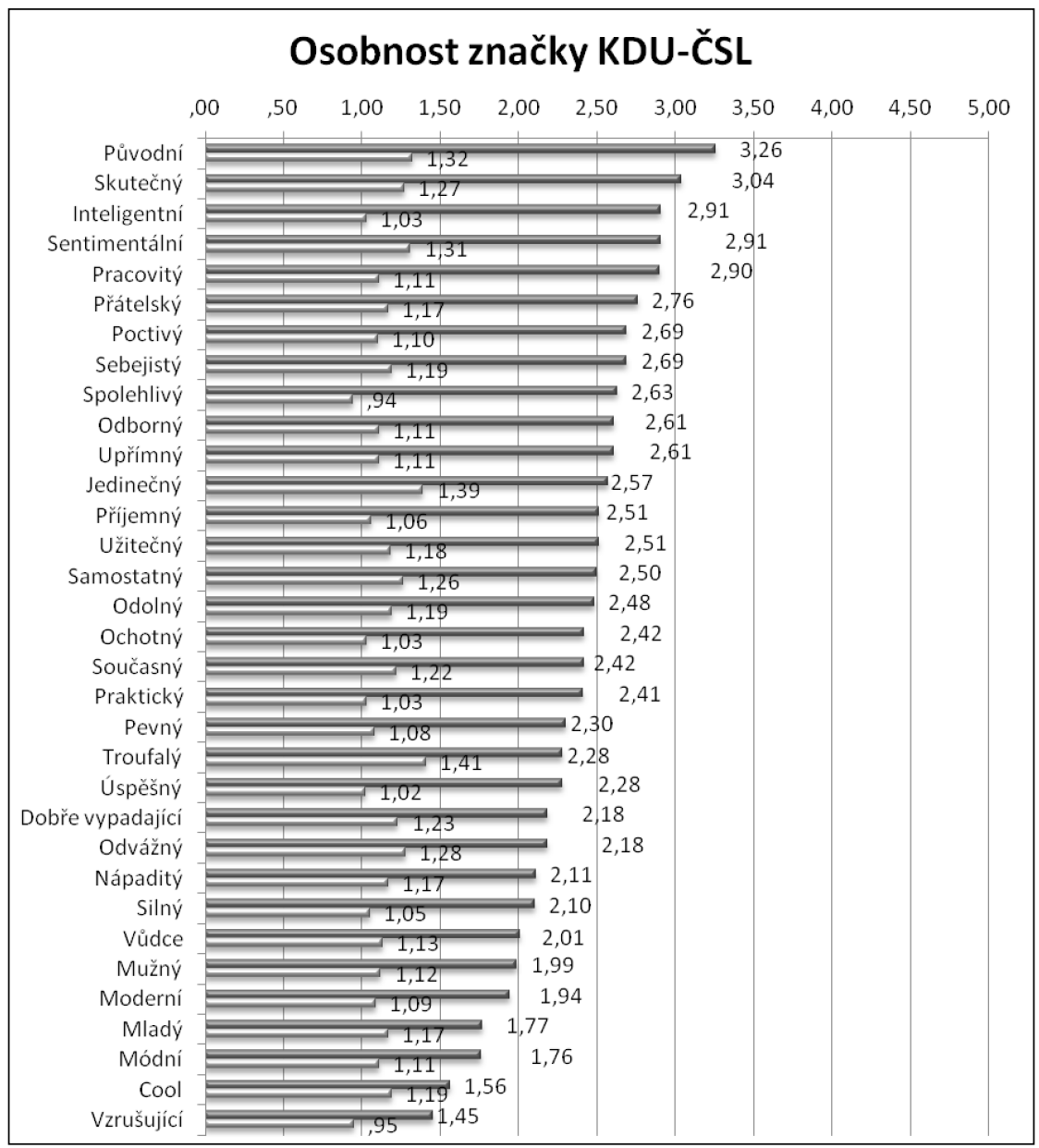

Graf 7: Osobnost značky KDU-ČSL (průměry a směrodatné odchylky)

KDU-ČSL respondenti nejvíce hodnotili jako původní stranu, kdy výsledný průměr byl 3,26 (variační koeficient 40,62 \%), druhý nejcharakterističtější znak pak představuje vnímání KDU-ČSL jako skutečné strany s průměrem 3,04 (variační koeficient 41,87 \%) a třetím znakem, který nabyl nejvyšší hodnoty průměru, je vnímání KDU-ČSL jako inteligentní s průměrem 2,91 (variační koeficient 35,1\%). Naproti tomu KDU-ČSL byla nejslaběji hodnocena jako módní (průměr 1,76 a variační koeficient 63,3\%), cool (průměr 1,56 a variační koeficient $76,21 \%$ ) a jako vzrušující (průměr 1,45 a variační koeficient $65,69 \%$ ). Celkem bylo $\mathrm{v}$ rámci výzkumu sebráno 81 dotazníků varianty KDU-ČSL. 


\section{Srovnání výsledků jednotlivých stran podle dimenzí}

Při použití škály jako měřicího nástroje je zároveň nutné testovat reliabilitu měření. Jak již bylo zmíněno, původní škála byla konstruována pro měření osobnosti britských politických stran. Test reliability nám tedy ukazuje, nakolik je škála vhodným nástrojem pro měření i pro české prostředí. Pro měření reliability byl proveden výpočet Cronbachova alfa zvlášt' pro každou z dimenzí škály. Výsledky pro jednotlivé dimenze shrnuje tabulka 3.

Tabulka 3: Vnitřní konzistence jednotlivých dimenzí osobnosti značky

\begin{tabular}{|l|c|c|}
\hline Dimenze & Počet indikátorů & Cronbachovo alfa \\
\hline Poctivost & 8 & 0,83 \\
\hline Odvaha & 5 & 0,74 \\
\hline Image & 7 & 0,85 \\
\hline Vedení & 7 & 0,83 \\
\hline Odolnost & 3 & 0,75 \\
\hline Jedinečnost & 3 & 0,56 \\
\hline
\end{tabular}

Výsledky podle jednotlivých dimenzí naznačují, že škála dosahuje poměrně vysoké reliability v jednotlivých dimenzích. Jedinou dimenzi, která dosahuje nízké míry reliability, pak představuje dimenze jedinečnosti. Pokud přihlédneme k rozdílnému historickému vývoji politických stran v obou zemích, je zjištění, že použité dimenze v původním výzkumu představují použitelné dimenze i v českém prostředí, poměrně překvapivé.

Jak již bylo zmíněno, srovnání výsledných průměrů u osobnosti značky je značně problematické, $\mathrm{z}$ důvodu nepř́lišs vypovídajících hodnot jednotlivých průměrů u osobnostních znaků. Následující tabulka uvádí dosažené průměry jednotlivých stran podle dimenzí škály. Výsledné hodnoty je potřeba posuzovat s ohledem na výše popsané skutečnosti, a výsledky tak pouze nastiňují, jak se liší vnímání osobnosti značek jednotlivých stran.

Tabulka 4: Srovnání výsledných prưměrů jednotlivých stran podle dimenzị

\begin{tabular}{|l|c|c|c|c|c|c|c|}
\hline Dimenze & ODS & ČSSD & TOP 09 & VV & KSČM & SZ & KDU-ČSL \\
\hline Poctivost & 2,63 & 2,11 & 2,84 & 2,4 & 2,17 & 2,62 & 2,69 \\
\hline Odvaha & 3,05 & 2,54 & 2,92 & 2,86 & 2,22 & 2,71 & 2,19 \\
\hline Image & 2,46 & 1,72 & 2,69 & 2,46 & 1,61 & 2,66 & 1,95 \\
\hline Vedení & 3,16 & 2,49 & 3,09 & 2,64 & 2,45 & 2,45 & 2,53 \\
\hline Odolnost & 2,94 & 2,47 & 2,78 & 2,34 & 2,39 & 2,17 & 2,19 \\
\hline Jedinečnost & 2,9 & 2,48 & 2,63 & 2,26 & 2,67 & 2,59 & 2,78 \\
\hline
\end{tabular}

9 Tmavou barvou jsou v tabulce označeny nejvyšší dosažené hodnoty průměrné hodnoty, světleji jsou pak zvýrazněny hodnoty nejnižší. 
Tabulka 4 ukazuje, jak se liší vnímání stran podle dimenzí. ODS a TOP 09 dosahují nejvyšších hodnot průměru $\mathrm{v}$ dimenzi vedení, kdy obě dosahují hodnot mírně nad průměrem škály (který je 3), jde tedy o kladné vnímání. ODS pak překročila hodnotu průměru škály v dimenzi odvaha. ČSSD, VV a SZ dosahují nejvyšších hodnot průměru v dimenzi odvaha. Jak ale můžeme vidět, průměry se pohybují pod průměrem škály, dle respondentů tedy osobnostní znaky shrnuté v daných dimenzích strany spíše necharakterizují. KSČM a KDU-ČSL dosáhly nejvyššího průměru $\mathrm{v}$ dimenzi jedinečnost, ovšem i $\mathrm{v}$ daném př́padě se průměry pohybují pod střední hodnotou škály a indikují, že podle respondentů dané osobnostní znaky strany spíše necharakterizují. Zajímavým zjištěním je skutečnost, že respondenti hodnotili pět stran (ODS, ČSSD, TOP 09, KSČM a KDU-ČSL) ze sedmi sledovaných nejníže v dimenzi image. VV pak byly nejslaběji hodnoceny v dimenzi jedinečnosti a SZ v dimenzi odolnost.

Tabulka 5: Srovnání výsledných prưměrů podle dimenzí - př̌znivci x odpưrciio

\begin{tabular}{|l|c|c|c|c|c|c|c|c|c|c|c|c|c|c|}
\hline & \multicolumn{2}{|c|}{ ODS } & \multicolumn{2}{|c|}{ ČSSD } & \multicolumn{2}{c|}{ TOP09 } & \multicolumn{2}{c|}{ VV } & \multicolumn{2}{c|}{ KSČM } & \multicolumn{3}{c|}{ SZ } & \multicolumn{2}{c|}{ KDU-ČSL } \\
\hline Dimenze & $\mathrm{P}$ & $\mathrm{O}$ & $\mathrm{P}$ & $\mathrm{O}$ & $\mathrm{P}$ & $\mathrm{O}$ & $\mathrm{P}$ & $\mathrm{O}$ & $\mathrm{P}$ & $\mathrm{O}$ & $\mathrm{P}$ & $\mathrm{O}$ & $\mathrm{P}$ & $\mathrm{O}$ \\
\hline Poctivost & 2,87 & 2 & 2,45 & 1,89 & 2,95 & 1,86 & 2,67 & 1,86 & 2,62 & 1,92 & 2,68 & 2,35 & 2,77 & 2,41 \\
\hline Odvaha & 3,15 & 2,78 & 2,73 & 2,42 & 2,94 & 2,74 & 2,98 & 2,63 & 2,68 & 1,93 & 2,76 & 2,49 & 2,21 & 2,09 \\
\hline Image & 2,57 & 2,17 & 1,85 & 1,64 & 2,77 & 1,96 & 2,61 & 2,15 & 2,12 & 1,3 & 2,74 & 2,36 & 2 & 1,78 \\
\hline Vedení & 3,33 & 2,68 & 2,81 & 2,29 & 3,12 & 2,8 & 2,81 & 2,3 & 2,74 & 2,26 & 2,48 & 2,37 & 2,59 & 2,27 \\
\hline Odolnost & 3,09 & 2,52 & 2,89 & 2,2 & 2,85 & 2,1 & 2,55 & 1,93 & 2,49 & 2,3 & 2,14 & 2,33 & 2,26 & 1,9 \\
\hline Jedinečnost & 3,14 & 2,25 & 2,6 & 2,4 & 2,72 & 1,9 & 2,41 & 1,94 & 2,95 & 2,48 & 2,6 & 2,55 & 2,86 & 2,45 \\
\hline
\end{tabular}

Zajímavým zjištěním, které můžeme vyčíst z tabulky 5 , je skutečnost, že tři sledované strany dosáhly nejlepšího výsledného průměru v jedné dimenzi jak u skupiny „,příznivců‘, tak i „odpůrců“. Těmito stranami jsou VV s nejvyšším dosaženým průměrem v dimenzi odvaha a KSČM spolu s KDU-ČSL v dimenzi jedinečnost. Naopak u ostatních sledovaných stran se hodnoty dosažených nejvyšších průměrů liší v rámci sledovaných skupin. U ODS, ČSSD a TOP 09 (a zároveň VV, které již byly zmíněny) vidíme, že skupina s negativním postojem ke zmíněným stranám hodnotila nejvýše znaky v dimenzi odvaha. V př́padě SZ pak vidíme, že skupina s negativním postojem ke straně hodnotila stranu nejvíce jako jedinečnou.

Pokud se naopak zaměříme na dimenze, v nichž strany dosáhly nejnižších hodnot, shodují se příznivci i odpůrci s nejnižším hodnocením u čtyř sledovaných stran. V případě ČSSD, KSČM a KDU-ČSL je to v dimenzi image. SZ pak obě skupiny nejslaběji hodnotí v dimenzi odolnost. U ODS, TOP 09 a VV respondenti s negativním postojem hodnotili strany nejméně $\mathrm{v}$ dimenzi poctivost. $\mathrm{V}$ př́padě ODS pak respondenti s pozitivním postojem ke straně tuto stranu hodnotili nejméně v dimenzi image a u TOP 09 a VV pak v dimenzi

10 Tmavou barvou jsou v tabulce označeny nejvyšší dosažené hodnoty průměrné hodnoty, světleji jsou pak zvýrazněny hodnoty nejnižší. 
jedinečnost. U TOP 09 se tak výsledek liší od celkového skóre, kdy byly počítány obě skupiny dohromady a kdy strana dosáhla nejnižšího výsledku v dimenzi image.

\section{Závěrečné shrnutí a krátká úvaha nad budoucími možnostmi výzkumu politických značek}

Pokud máme zodpovědět otázku, jak jsou vnímány české politické strany, z představených výsledků vyplývá, že v případě jednotlivých osobnostních znaků byly české politické strany nejčastěji vnímány jako sebejisté (v prrípadě ODS a ČSSD šlo o znak s nejvyšším průměrem, u VV a KSČM pak o znak na druhém místě a u TOP 09 na třetím). Je ovšem otázkou, jak dané zjištění interpretovat, nebot' „sebejistota“ v sobě může nést značný negativní náboj, kdy si ji respondenti spojují spíše s určitou arogancí, tedy s tím, že strany jsou si samy sebou jisté. Podobně problematické je vnímání stran jako troufalých, protože kromě roviny, podle níž daná skutečnost může indikovat rozhodnost stran, může v sobě opět nést negativní náboj ve smyslu, že strany si dovolují činit i kroky, které voliči vnímají silně negativně. Jako troufalou označovali respondenti KSČM, kde byla „troufalost“ nejsilnějším znakem, ODS a ČSSD, kdy byla druhým nejsilnějším znakem a VV, kdy představovala třetí nejsilnější znak.

V prŕípadě obou nových stran TOP09 a VV byla znakem s nejvyšší průměrnou hodnou „současnost“", kterou si pak na druhém místě respondenti spojovali se SZ a na třetím místě s ODS. U TOP09 se na druhém místě objevil osobnostní znak ,inteligentní“, který byl i na třetím místě u KDU-ČSL. Poslední znak, který byl společný alespoň dvěma stranám, představuje vnímání stran jako „původních“; šlo o nejsilnější znak u KDU-ČSL a třetí nejsilnější u KSČM. SZ pak byla jako jediná vnímána jako „mladá“ (nejsilnější znak) a „moderni““ (tř̌etí nejsilnější znak). U ČSSD se objevilo vnímání strany jako „odolné“ (třetí nejsilnější asociace) a v př́ípadě KDU-ČSL jako „skutečné“ (druhý nejsilnější znak). Znovu však připomínáme prozatímnost těchto zjištění, související s faktem, že neexistuje př̌esnější informace o tom, jaké je postavení jednotlivých znaků (zejména jejich konotace) v rámci českého sémantického pole.

Při srovnání průměrů jednotlivých dimenzí můžeme strany rozdělit do tří skupin, kdy první skupinu představují ODS a TOP 09, které si respondenti nejsilněji spojují s dimenzí vedení. Druhou skupinu pak představují ČSSD, VV a SZ, které si respondenti nejsilněji spojují se znaky z dimenze odvaha. Poslední skupinu pak představují KDU-ČSL a KSČM, které jsou nejsilněji spojovány s dimenzí jedinečnost. Pokud se ovšem podíváme na výsledné hodnoty, zjistíme, že s výjimkou ODS u znaků vedení a odvaha, a TOP 09 u znaku vedení, dosahují výsledné průměry hodnot nižších než tři, čili hodnoty nižší, než je průměr škály, na které byly znaky měřeny. Můžeme tak říci, že podle respondentů dané znaky v jednotlivých dimenzích strany spíše necharakterizují.

Při porovnání průměrů jednotlivých dimenzí u výsledků rozdělených na základě postoje respondentů ke sledovaným stranám je zajímavým zjištěním, že respondenti s negativním postojem ke straně celkem u čtyř stran - ODS, ČSSD, TOP 09 a VV - hodnotili strany nejvyšším průměrem v dimenzi odvaha. Při bližším pohledu na výsledné hodnoty pro jednotlivé znaky můžeme konstatovat, že dané průměry nejvíce zvyšují výsledné hodnoty průměru u znaku „troufalý.“ Pravděpodobně se i zde projevuje již zmíněná nejednoznačnost daného 
znaku, který v sobě implicitně nese i negativní náboj. Je velmi pravděpodobné, že respondenti s negativním postojem ke sledovaným stranám daný znak chápali právě v negativním významu, a proto mu přidělovali vyšší hodnoty. Ovšem daný předpoklad je poněkud komplikován skutečností, že znak troufalý dosahuje vysokých hodnot i u respondentů, kteří vyjádřili pozitivní (respektivě neutrální) postoj ke sledovaným stranám, a zároveň nedosahoval př́liš vysokých hodnot u dvou ze sledovaných stran SZ a KDU-ČSL ani u jedné z obou vymezených skupin respondenti̊.

V př́padě otázky existence jednotného povědomí o značkách českých politických stran můžeme konstatovat, že v myslích prvovoličů nejsou etablovány konzistentní obrazy osobností značek jednotlivých politických stran v České republice. Dané tvrzení je poněkud komplikováno skutečností, že u skupiny respondentů, kteří ke sledovaným stranám vyjádřili kladný postoj, jsou výsledné hodnoty souhrnných průměrů variačních koeficientů nižší než u skupiny s negativním postojem, a to ve vztahu ke všem sledovaným politickým stranám. Je tedy možné říci, že obraz jednotlivých značek je u skupiny „př́íznivcư“ konzistentnější než u skupiny, která vyjádřila ke stranám negativní postoj. Přesto ale zůstávají souhrnné hodnoty variačních koeficientů stále značně vysoké, a naše tvrzení o neschopnosti českých politických stran etablovat v myslích svých voličů ucelený obraz svých značek lze proto spíše podržet.

Testování reliability ukázalo, že s výjimkou dimenze jedinečnosti lze využít v českém prostředí dimenze škály osobnosti jako v prípadě původní studie Garetha Smitha. Jak bylo nastíněno, jedná se o poměrně překvapivé zjištění, obzvlášt' jestliže si uvědomíme, že škála byla vytvořena pro měření osobnosti značek politických stran, které prošly velmi odlišným historickým vývojem v rámci zcela odlišného stranického systému.

Celkově lze shrnout - a to i při vědomí nejrůznějších omezení, na něž se text rovněž snažil upozornit -, že zvolená perspektiva, orientující se na vnímání politických značek jejich voliči, představuje jeden $\mathrm{z}$ potenciálně slibných směrů budoucího výzkumu, který může poskytnout hlubší vhled do motivací, které utvářejí a určují volební chování.

\section{Literatura}

AAKER, Jenifer L. Dimension of Brand Personality. Journal of Marketing Research, 1997, roč. 34, č. 3, s. 347-356. ISSN: 0022-2437.

AAKER, David A. Brand Building: Budování značky. Brno: Computer Press, 2003. 312 s. ISBN: 8-07226-885-6.

AZULAY, Audrey; KAPFERER, Jean-Noël. Do Brand Personality Scales Really Measure Brand Personality? Journal of Brand Managment, 2003, roč. 11, č. 2, s. 143-155. ISSN: 1479-1803.

AUSTIN, Jon; SIGAUW, Judy; MATTILA, Anna. A Re-Examination of the Generalizability of the Aaker Brand Personality Measurement Framework. Journal of Strategic Marketing, 2003, roč. 11, č. 2, s. 143-155. ISSN: 0965-254X.

COX, Gary W.; McCUBBINS, Mathew D. Electoral Politics as a Redistributive Game, Journal of Politics, 1986, roč. 48, č. 2, s. 370-389. ISSN: 00223816.

de CHERNATONY, Leslie. Značka - od vize k vyššim ziskům. Brno: Computer Press, 2009. 315 s. ISBN: 978-80-251-2007-1. 
DALTON, Russell J. The Decline of Party Identification: Political Change in Advanced Industrial Democracies. In DALTON, R. J., Wattenberg M. P. (eds.) Parties without Partisans. Oxford: Oxford University Press, 2000, s. 19-36. ISBN: 0-19924-082-5 (9780199240821).

DOWNS, Anthony. An Economic Theory of Democracy. Boston: Addison-Wesley, 1957. 310 s. ISBN: 0-06041-750-1.

EIBL, Otto. Volební programy. In BALÍK, S. a kol. Volby do Poslanecké sněmovny v roce 2010. Brno: CDK, 2010, s. 69-96. ISBN: 978-80-7325-224-3.

CHYTILEK, Roman; EIBL, Otto. České politické strany v politickém prostoru, Sociologický časopis/ Czech Sociological Review, 2011, roč. 47, č. 1, s. 61-88. ISNN: 1211-3247.

KELLER, Kevin L. Conceptualizing, Measuring and Managing Customer-Based Brand Equity. Journal of Marketing, 1993, roč. 57, č. 1, s. 1-22. ISNN: 0022-2429.

KELLER, Kevin L. Strategické ř́zení značky. Praha: Grada Publishing, 2007. 796 s. ISBN: 978-80-2471481-3.

KOPEČEK, Lubomír. Politické strany a stranické systémy ve srovnávací a teoretické perspektivě. In STRMISKA, M., HLOUŠEK, V., KOPEČEK, L., CHYTILEK, R. Politické strany moderni Evropy, Brno, Portál, s. 9-52. ISBN: 80-7367-038-0.

LIPSET, Seymour M.; ROKKAN, Stein. Party Systems and Voter Alignments: Cross National Perspective. New York: The Free Press, 1967. 554 s. ISBN: 000184338

OHANIAN, Roobina. Construction and Validation of a Scale to Measure Celebrity Endorsers' Perceived Expertise, Trustworthiness and Attractiveness. Journal of Advertising, 1990, roč. 19, č. 3, s. 39-52. ISSN: 0091-3367.

O'SHAUGHNESSY, Nicholas J. The Symbolic State: A British Experience, Journal of Public Affairs, 2003, roč.3, č. 4, s. 297-312. ISSN: 1472-3891.

O'SHAUGHNESSY, Nicholas J.; HENNEBERG, Stephan C. The Selling of President 2004: A Marketing Perspective, Journal of Public Affairs, 2007, roč. 7, č. 3, s. 249-268. ISSN: 1479-1854.

PLUMMER, Joseph T. How Personality Makes a Difference, Journal of advertising research, 1984, roč. 24, č. 6, s. 27-31. ISSN: 0021-8499.

SCAMMELL, Margaret. Political Brands and Consumer Citizens: The Rebranding of Tony Blair, The ANNALS of the American Academy of Political and Social Science, 2007, č. 1, s. 176-192. ISSN: 1552-3349.

SHNEIDER, Helmut. Branding in Politics - Manifestations, Revelance and Identity-oriented Managment. Journal of Political Marketing, 2004, roč. 3, č. 3, s. 41-67. ISSN: 1537-7865.

SINGER, Claude. Bringing Brand Savvy to Politics [on-line]. 2002 [cit. 2011-11-27]. Dostupné na www: $<$ www.allbusiness.com/marketing-advertising/branding-brand-development/4675738-1.html>

SMITH, Gareth. Connceptualizing and Testing Brand Personality in British Politics. Journal of Political Marketing, 2009, roč. 8, č. 3, s. 209-232. ISSN: 1537-7865.

SMITH, Gareth; FRENCH, Alan. Measuring Political Brand Equity: A Consumer Oriented Approach. European Journal of Marketing, 2007, roč. 44, č. 3, s. 460-477. ISNN: 0309-0566.

SMITH, Gareth, FRENCH, Alan. The Political Brand: A Consumer Perspective. Marketing Theory, 2009, roč. 9, č. 2, s. 209-226. ISSN: 1470-5931.

STOKES, Susan C. Perverse Accountability: A Formal Model of Machine Politics with Evidence from Argentina. American Political Science Review, 2005, roč. 99, č. 3, s. 315-25. ISSN: 0003-0554.

TOMZ, Michael; SNIDERMAN, Paul M. Brand Names and the Organisation of Mass Belie systems [on-line]. 2005 [cit. 2011-11-27]. Dostupné na www: < www.stanford.edu/ tomz/working/ TomzSniderman2005> 


\section{Autoři}

Jiři Šimon vystudoval politologii na Katedře politologie FSS MU. V současné době působí jako externí spolupracovník u agentury zabývající se výzkumy trhu.

Kontakt:182516@muni.mail.cz

Roman Chytilek je vedoucím magisterské specializace Volební studia a politický marketing na Katedře politologie FSS MU.

Kontakt chytilek@fss.muni.cz 